\title{

}

JURNAL PENELITIAN BAHASA, SASTRA, DAN

BUDAYA ARAB

P-ISSN: 2615-7241 | E-ISSN: 2721-480X // Vol. 2 No. 1 | 58-68

๑) https://ejournal.upi.edu/index.php/alsuniyat/index

\section{PENERAPAN METODE EDUTAINMENT MELALUI PERMAINAN SIMAK- ULANG-UCAP UNTUK MENINGKATKAN KETERAMPILAN BERBICARA BAHASA ARAB}

\author{
Karimna Isya Karima \\ MTs Ar-Rohmah Bandung, Indonesia \\ E-mail: karimnaisya18@gmail.com
}

\begin{abstract}
:
This research based on the first grade of MTs Ar-Rohmah's students'Arabic speaking skills. It was caused by the lack of application of in speaking Arabic. The students often feels bored and lack of confidence. So, the researcher was interested to find out differences in student's speaking skill using Edutainment method. This study used quantitative approach, and quasi-experimental methodology. The techniques of collecting data are observation, interviews, test learning instruments, and documentation. The results are: (1) The mean value of experimental class' pre-test has 41,25. Meanwhile in the control class has 51,40. (2) The mean value of experimental class' post test has 63,43, meanwhile the control class has 59,68. (3) N-Gain Score's test shows there was an increase in experimental class amounts $43.94 \%$ or 0,43 which in the average category. Besed on the results, the application of Edutainment method with 'Listen-Repeat-Speak' games can improve Arabic speaking skills.
\end{abstract}

Keywords:

Edutainment Method; Speaking Skills; Listen Repeat and Speak Games

\begin{abstract}
Abstrak
Penelitian ini dilatarbelakangi oleh rendahnya keterampilan berbicara bahasa Arab siswa kelas VIIB MTs ArRohmah. Hal ini disebabkan karena kurangnya upaya penerapan dalam berbicara dan metode pembelajaran yang kurang variatif, sehingga siswa merasa jenuh dan kurang percaya diri ketika berbicara menggunakan bahasa Arab. Peneliti tertarik untuk meneliti keterampilan berbicara siswa menggunakan metode Edutainment. Penelitian ini menggunakan pendekatan kuantitatif dan metodologi penelitian eskperimen kuasi. Teknik pengumpulan data menggunakan observasi, wawancara, instrumen test, instrumen pembelajaran, dan dokumentasi. Hasil dari penelitian ini adalah (1) Rata-rata nilai pre-test kelas eksperimen adalah 41,25 sedangkan kelas kontrol 51,40. (2) Rata-rata nilai post-test kelas eksperimen adalah 63,43 sedangkan kelas kontrol 59,68. (3) Hasil uji N-Gain Score menunjukkan kenaikan pada kelas eksperimen sebesar 43.94\% atau 0,43 yang termasuk kategori Average atau cukup. Oleh karena itu, penerapan metode Edutainment dengan permainan simak-ulang-ucap dapat meningkatkan keterampilan berbicara bahasa Arab siswa.
\end{abstract}

Kata Kunci:

Metode Edutainment; Keterampilan Berbicara; Permainan Simak-Ulang-Ucap

\section{PENDAHULUAN}

Bahasa Arab merupakan bahasa yang memiliki kaitan erat dengan umat Islam. Sebab, Bahasa Arab adalah satu-satunya jalan untuk memahami dan mengetahui ajaran Islam. Tidak hanya itu, Bahasa Arab juga memiliki peran dalam dunia pendidikan, yaitu sebagai sarana dalam penyampaian ilmu pengetahuan.

Menurut taufik (dalam Shalihah, 2018) ada empat keterampilan yang harus dikuasai oleh murid ketika mempelajari Bahasa Arab. Empat keterampilan tersebut adalah: Keterampilan membaca (qirā'ah), keterampilan menulis (kitābah), keterampilan menyimak 
ALSUNIYAT: Jurnal Penelitian Bahasa, Sastra, dan Budaya Arab

(istimā') dan keterampilan berbicara (takallum). Keempat keterampilan tersebut saling berkaitan dan saling mempengaruhi. Tidak terkecuali, keterampilan berbicara (takallum) yang merupakan keterampilan pokok dalam belajar bahasa.

Keterampilan berbicara (mahārat al-Kalām) adalah kemampuan untuk mengucapkan kata-kata dengan aturan-aturan kebahasaan (qawā'id naḥwiyyah wa șarfiyyah) tertentu untuk menyampaikan ide-ide dan perasaan. Sulastri (2016:24) mendefinisikan pembelajaran keterampilan berbicara merupakan keterampilan produktif (mahârat al-intâjiyah/productive skills) dalam berbahasa. Keterampilan ini memerlukan informasi yang memadai untuk mengkomunikasikan informasi yang memadai serta mengungkapkan maksud dan gagasan agar tersampaikan dengan baik.

Selaras dengan pernyataan di atas, Iskandarwassid dan Sunendar (2011:41) menandaskan bahwa keterampilan ini didasari oleh kepercayaan yang tinggi untuk berbicara secara jujur, benar, dan bertanggung jawab. Dengan demikian, keterampilan berbicara dapat menghilangkan sejumlah masalah psikologis seperti rasa malu, rendah diri, ketegangan, dan sebagainya.

Lebih lanjut, Effendy (2009:129) mengungkap bahwa latihan berbicara harus didasari oleh kemampuan mendengarkan dan penguasaan mufradāt dan ungkapan. Hal-hal tersebut yang memungkinkan peserta didik untuk dapat mengkomunikasikan maksud, gagasan, dan pikirannya. Hal ini sejalan dengan apa yang dikatakan oleh Arsjad dan Mukti U.S (dalam Armani, 2013:3) yang menegaskan bahwa kemampuan berbicara adalah kemampuan mengucapkan bunyi-bunyi artikulasi atau mengucapkan kata-kata untuk mengekspresikan, menyatakan, menyampaikan pikiran, gagasan dan perasaan.

Dewasa ini, pembelajaran keterampilan berbicara bahasa Arab telah diterapkan di berbagai institusi, khususnya di institusi formal. Namun, peserta didik seringkali masih menemukan kesulitan dalam mempelajari bahasa Arab. Kesulitan tersebut dialami oleh sebagian besar siswa Madrasah Tsanawiyah Ar-Rohmah, yang memiliki mata pelajaran Bahasa Arab. Akan tetapi, hasil belajar mata pelajaran bahasa Arab di Madrasah Tsanawiyah Ar-Rohmah Kota Bandung sendiri belum mencapai hasil yang diharapkan, khususnya pada keterampilan berbicara. Padahal, keterampilan berbicara ini merupakan kunci dalam mengungkapkan ide atau maksud dan tujuan.

Berbicara merupakan hal yang harus dilatih secara terus menerus. Melalui latihan, maka aspek-aspek keterampilan berbicara dapat terus berkembang. Ros \& Roe (dalam Ratnasari, 
dkk., 2016:2) juga mengemukakan bahwasanya keterampilan berbicara lebih mudah dikembangkan apabila peserta didik mendapat kesempatan untuk mengomunikasikan sesuatu secara alami dalam kesempatan yang bersifat informal.

Metode Pembelajaran menurut oleh Slameto (dalam Mariyaningsih dan Hidayati, 2018:10) metode pembelajaran adalah suatu cara atau jalan yang harus dilalui dalam mengajar. Dari beberapa pengertian di atas maka dapat disimpulkan bahwa metode pembelajaran adalah cara yang digunakan untuk mencapai tujuan pembelajaran yang telah disusun. Adapun beberapa ciri dari metode pembelajaran tersebut dapat dikatakan efektif. Mariyaningsih dan Hidayati (2018:11) mengungkapkan ciri-ciri yang dapat dijadikan acuan untuk menilai efektif tidaknya sebuah metode pembelajaran di antaranya adalah; meningkatkan pemahaman siswa terhadap materi pembelajaran, membuat siswa merasa tertantang, membangun rasa keingintahuan siswa, meningkatkan keaktifan siswa, merangsang daya kreatifitas siswa, dan mudah dilaksanakan oleh guru.

Mukrima (2014:52) menyebutkan ada prinsip umum dalam memilih metode pembelajaran, diantaranya adalah berorientasi pada tujuan pembelajaran, aktivitas peserta didik, tujuan individualitas, dan integritas. Oleh karena itu, salah satu metode yang tepat dan sesuai dalam pembelajaran bahasa Arab khususnya dalam pembelajaran berbicara (takallum) adalah metode Edutainment.

Agustriana (2013:5) Edutainment merupakan kombinasi dari fungsi pendidikan dan konten yang berbentuk hiburan. Tujuannya untuk menciptakan lingkungan belajar yang menarik. Dengan metode Edutainment, proses pembelajaran di sekolah akan menyenangkan. Anak-anak tidak merasa jenuh atau bosan. Pembelajaran menjadi lebih bermakna dalam kehidupan sehari-hari. Edutainment memiliki unsur 3R, yaitu Relevance, Relationship, dan Responsibility.

Berdasarkan uraian di atas, salah satu bentuk upaya untuk menjadikan pembelajaran lebih menyenangkan dalam pembelajaran takallum, peneliti memilih permainan simak-ulangucap sebagai media pembelajaran. Permainan ini menitikberatkan pada kemampuan menyimak serta kemampuan berbicara siswa. Tarigan (dalam Suryani, 2012:6) mengatakan bahwa metode simak ulang ucap biasanya digunakan dalam memperkenalkan bunyi bahasa dan cara mengucapkannya. Guru membacakan, mengucapkan, atau memutar rekaman bunyi bahasa tertentu, dengan fonem, kata, kalimat jelas dan intonasi yang tepat. Kemudian siswa diminta untuk meniru ucapan guru. 
Selanjutnya, Muktar dan Anilawati (dalam Suryani, 2012:7) menjelaskan pada permainan ini guru mengucapkan sejumlah kata yang kemudian akan diulang oleh siswa. Guru memberikan variasi dalam mengucapkan kata yang akan diulang oleh siswa. Siswa pun dituntut untuk membunyikan bahasa dengan benar. Hal ini sangat cocok bagi pemula. Karena, guru mengajarkan pengucapan secara tepat saat belajar bahasa asing dan ejaan yang sesuai dalam bahasa asing.

Berdasarkan hal tersebut, fokus dalam penelitian ini adalah penerapan metode Edutainmnet melalui permainan simak-ulang-ucap untuk meningkatkan keterampilan berbicara bahasa Arab.

\section{METODE}

Penelitian ini dilaksanakan di MTs Ar-Rohmah Kota Bandung yang terletak di Jl. Sukajadi No. 140 Kecamatan Sukajadi Kota Bandung. Penelitian ini merupakan penelitian Eksperimen Semu (Quasi Experimental) dengan menggunakan dua kelas yaitu kelas VII B sebagai kelas eksperimen serta kelas VII A sebagai kelas kontrol dengan jumlah masingmasing kelasnya sebanyak 32 siswa. Dalam penelitian ini, kelas eksperimen (VII B) diberi perlakukan treatment dengan menggunakan metode Edutainment ketika pembelajaran Bahasa Arab berlangsung. Sedangkan kelas kontrol (VII A) tidak diberi perlakuan atau treatment ketika pembelajaran Bahasa Arab berlangsung.

Data hasil penelitian ini dikumpulkan melalui dua jenis test, yaitu pre-test dan post-test. Sebelum melakukan pre-test dan post-test, peneliti melakukan uji validasi dan uji reliabilitas instrument ke kelas VIII B MTs Ar-Rohmah. Uji coba ini dilakukan untuk mengetahui apakah instrumen yang dibuat oleh peneliti layak untuk diujikan kepada sampel penelitian. Dalam penelitian ini, peneliti melakukan uji instrumen dengan menggunakan Microsoft Excel.

Peneliti menggunakan instrumen pre-test dan post-test secara lisan. Adapun pedoman penilaian tiap aspek dalam test tersebut berdasarkan pada pendapat Effendy (dalam Nisa', 2015:55) mengenai aspek-aspek yang dinilai dalam kegiatan berbicara, sebagaimana disarankan oleh para ahli, adalah sebagai berikut: 1) Aspek kebahasaan yang meliputi pengucapan (makhraj), nada dan irama, pilihan kata, pilihan ungkapan, dan susunan kalimat. 2) Aspek non-kebahasaan yang meliputi kelancaran, penguasaan topik, keberanian, keterampilan, penalaran, ketertiban, dan kerjasama. 
Peneliti lalu memilih lima aspek dalam penelitian yaitu: pengucapan, pilihan kata, kelancaran, penguasaan topik, dan keberanian.

\section{HASIL DAN PEMBAHASAN}

\section{Hasil Pre-test}

Deskripsi data hasil pre-test dapat dilihat dalam tabel di bawah ini:

Tabel 1

Hasil Penghitungan Nilai Pre-Test

\begin{tabular}{|l|l|l|}
\hline Data & Kelas Kontrol & Kelas Eksperimen \\
\hline $\mathrm{N}$ & 32 & 32 \\
\hline Min & 2 & 25 \\
\hline Max & 90 & 70 \\
\hline Rata-rata & 51,40 & 41,25 \\
\hline Standar Deviasi & 17,284823 & 13,61925 \\
\hline
\end{tabular}

Berdasarkan data pada Tabel 1, hasil pre-test di kelas eksperimen memiliki nilai tertinggi $=70$, nilai terendah $=25$, dan rata-rata nilai sebesar 41,25 . Sedangkan pada kelas kontrol, nilai tertinggi adalah $=90$, nilai terendah $=25$, dan rata-rata nilai $=51,40$. Dari hasil tersebut juga diperoleh standar deviasi pada kelas eksperimen adalah 13,61925, sedangkan pada kelas kontrol adalah 17,284823.

\section{Hasil Post-test}

\section{Tabel 2}

Hasil Penghitungan Nilai Post-test

\begin{tabular}{|l|l|l|}
\hline Data & Kelas Kontrol & Kelas Eksperimen \\
\hline $\mathrm{N}$ & 32 & 32 \\
\hline Min & 35 & 25 \\
\hline Max & 80 & 85 \\
\hline Rata-rata & 59.68 & 63,43 \\
\hline Standar Deviasi & 12.374368 & 16,72536706 \\
\hline
\end{tabular}

Dari tabel di atas, hasil minimal pada kelas kontrol adalah 35, sedangkan pada kelas eksperimen adalah 25. Nilai tertinggi yang dimiliki oleh kelas kontrol adalah sebesar 80, sedangkan kelas eksperimen adalah 85. Nilai rata-rata untuk kelas kontrol adalah 59.68 dan 
ALSUNIYAT: Jurnal Penelitian Bahasa, Sastra, dan Budaya Arab

standar deviasi kelas kontrol adalah 12.374368. Sedangkan untuk kelas eksperimen memiliki rata-rata 63,43 dan standar deviasinya adalah $16,72536706$.

Peneliti menggunakan uji normalitas untuk mengetahui keabsahan sampel dari populasi. Sampel dikatakan berdistribusi normal apabila nilai yang diperoleh berasal dari populasi yang berdistribusi normal. Hasil pre-test kelas eksperimen dan kelas control masing-masing berdistribusi Sig. 0,20 dan Sig. 0,112. Keduanya dinyatakan normal karena masing-masing memiliki distibusi nilai Sig. > 0,05. Peneliti kemudian menggunakan langkah yang sama pada hasil post-test. Hasil post-test juga dinyatakan berdistribusi normal karena kelas eksperimen memiliki distribusi nilai Sig. 0,69 dan Sig. 0,316.

Peneliti kemudian melakukan uji homogenitas untuk mengetahui keberagaman data yang diperoleh dari dua atau lebih kelompok bersifat homogen atau heterogen. Uji homogenitas ini merupakan persyaratan untuk uji hipotesis. Peneliti memperoleh nilai Sig. 0,62 pada hasil pre-test dan 0,570 pada hasil post-test. Maka, dapat disimpulkan kedua hasil test tersebut bersifat homogen karena distribusi nilai Sig. $>0,05$.

Setelah data bersifat normal dan homogen, maka tahap selanjutnya adalah menguji hipotesis apakah ada perbedaan pada hasil belajar siswa dari sample yang berpasangan. Dalam uji hipotesis ini, peneliti menggunakan uji Simple Paired T-test. Hasil uji Simple Paired T-test, menunjukkan perolehan. Sig (2-tailed) sebesar 0,000 $<0,05$ yang artinya hipotesis ada perubahan pada hasil belajar siswa diterima. Setelah itu, peneliti melakukan uji Independent Sample T-test. Tujuan dari dilakukannya test ini adalah menguji hipotesis apakah ada perbedaan pada hasil belajar siswa dari sample yang tidak berpasangan.

Peneliti memperoleh nilai Sig. 2-tailed sebesar 0,021. Dapat diketahui dari nilai signifikasi (Sig. 2-tailed) hasil post-test tersebut menunjukkan bahwa 0,021<0,05. Artinya, kedua kelas mengalami kenaikan pada hasil belajar.

\section{Peningkatan (Gain)}

Data gain yang diperoleh oleh siswa setelah penerapan metode Edutainment dapat terlihat dalam deskripsi tabel di bawah ini: 
Tabel 3

Deskripsi Hasil Uji $N$-Gain Score

\begin{tabular}{|l|l|l|}
\hline \multicolumn{1}{|c|}{ Hasil } & \multicolumn{1}{|c|}{ Kelas Eksperimen } & \multicolumn{1}{c|}{ Kelas Kontrol } \\
\hline Rata-rata N-Gain & $43,9457(0,43 \%)$ & $6,1095(0,061 \%)$ \\
\hline Minimal & 00,00 & $-20,00$ \\
\hline Maksimal & 83,33 & 58,33 \\
\hline
\end{tabular}

Dari tabel di atas, rata-rata kelas eksperimen menunjukkan angka sebesar $43.94 \%$ atau sebesar 0.43\%. Menurut Hake (dalam Sundayana, 2016), berikut tafsiran interpretasi indeks Gain Ternormalisasi (g) yang sudah dimodifikasi:

Tabel 4

Tafsiran Interpretasi Indeks Gain

\begin{tabular}{|c|c|}
\hline Normalized Gain Score & Interpretation \\
\hline$-1,00<\mathrm{g}<0,00$ & Decrease \\
\hline $\mathrm{G}=0,00$ & Stable \\
\hline $0,00<\mathrm{g}<0,30$ & Low \\
\hline $0,30<\mathrm{g}<0,70$ & Average \\
\hline $0,70<\mathrm{g}<1,00$ & High \\
\hline
\end{tabular}

Berdasarkan tafsiran tersebut, maka nilai rata-rata $\mathrm{N}$-Gain pada kelas eksperimen termasuk dalam kategori Average.

\section{Pembahasan}

Berdasarkan hasil yang telah dianalisis dengan uji statistik parametrik, terdapat perbedaan rata-rata pada hasil pre-test dan post-test keterampilan berbicara siswa. Hasil pretest siswa kelas eksperimen memiliki rata-rata nilai sebesar 4,25. Sedangkan, hasil post-test siswa kelas eksperimen setelah diterapkannya metode Edutainment melalui permainan simak-ulang-ucap memiliki rata-rata nilai sebesar 63,43.

Hal ini disebabkan adanya penggunaan metode Edutainment memiliki tujuan utama untuk mengenalkan pembelajaran kepada siswa melalui eksplorasi, interaksi, trial and error, dan latihan. Sehingga, siswa menikmati suasana kelas yang menyenangkan, tanpa menyadari bahwa mereka sedang belajar. 
ALSUNIYAT: Jurnal Penelitian Bahasa, Sastra, dan Budaya Arab

Setelah diterapkannya metode Edutainment, siswa lebih percaya diri untuk mengucapkan kosakata bahasa Arab. Hasil post-test di kelas eksperimen menunjukkan ratarata nilai yang lebih besar jika dibandingkan dengan kelas kontrol. Dengan begitu, dapat dikatakan bahwa metode Edutainment dapat meningkatkan keterampilan berbicara yang dimiliki siswa. Pada treatment yang dilakukan, siswa belajar dengan cara mengeksplorasi, berinteraksi dengan kelompoknya, trial and error, dan latihan. Adanya unsur hiburan berupa permainan, siswa terhanyut dalam kompetisi dari permainan tersebut. Sehingga, siswa tidak menyadari pada saat yang sama mereka sedang meningkatkan keterampilan berbicara bahasa Arab yang mereka miliki. Hal ini merupakan kelebihan dari metode Edutainment. Seperti yang diungkapkan oleh Rokib (dalam Maghfuro dan Adrianingsih, 2014:3), kelebihan dari metode Edutainment adalah membuat anak merasa senang dan membuat belajar menjadi terasa lebih mudah.

Selain itu, siswa pun belajar mengenai cara pengucapan kosakata bahasa Arab yang benar melalui permainan simak-ulang-ucap. Siswa pun dituntut untuk membunyikan bahasa dengan benar. Langkah ini sangat cocok bagi pembelajaran bahasa untuk pemula, yaitu dengan mengajarkan pengucapan secara tepat sehingga dapat mencapai tujuan dari pembelajaran keterampilan berbahasa Arab sesuai dengan yang dikemukakan oleh Izzan (dalam Harahap, 2017:157) agar melatih lidah peserta didik agar terbiasa dan fasih ketika berbicara, terampil dalam berbicara, mampu menerjemahkan percakapan lawan bicara, dan menumbuhkan rasa cinta dan keinginan untuk mendalami bahasa Arab.

Permainan simak-ulang-ucap juga melatih siswa untuk berkonsentrasi belajar. Siswa dituntut untuk berkonsentrasi ketika menyimak dan berbicara bahasa Arab. Tujuannya agar materi pembelajaran dapat terekam sebaik mungkin di pikiran siswa. Hal ini sejalan dengan apa yang dikatakan oleh Nuryana dan Purwanto (2010:89), salah satu faktor yang dipercaya dapat membawa keberhasilan anak didik dalam mencapai tujuan pembelajarannya adalah konsentrasi yang baik.

Hasil yang telah diperoleh peneliti tersebut kemudian diperkuat dengan adanya uji statistik parametrik. Sebelum melakukan uji statistik parametrik, peneliti melakukan uji normalitas dan homogenitas terlebih dahulu untuk mengetahui apakah data berdistribusi normal dan homogen. Kelas eksperimen memiliki signifikasi sebesar 0,069 > 0,05. Sedangkan kelas kontrol memiliki signifikasi sebesar 0,316 > 0,05. Maka, dapat disimpulkan bahwa data 
penelitian berdistribusi normal. Setelah itu, peneliti melakukan uji homogenitas. Uji homogenitas ini merupakan persyaratan untuk uji Independent Sample T-test.

Uji homogenitas menunjukkan hasil pre-test bersifat homogen karena nilai $=$ Sig. 0,62 > 0,05. Hasil post-test juga menunjukan nilai $=$ Sig. 0,570 > 0,05. Artinya, data post-test bersifat homogen. Setelah diketahui data bersifat homogen, peneliti kemudian menguji kembali hasil tersebut. Peneliti melakukan uji Independent Sample T-test.

Uji Independent Sample T-test dilakukan untuk mengetahui ada tidaknya perbedaan rata-rata. Jika nilai signifikansi (2-tailed) < 0.05 menunjukkan adanya perbedaan rata-rata antar subjek penelitian. Pada penelitian ini, nilai signifikasi (Sig. 2-tailed) yang diperoleh pada hasil post-test sebesar 0,021<0,05. Artinya, ada perbedaan rata-rata pada hasil belajar siswa.

Pada uji Independent Sample T-test, peneliti memperoleh hasil signifikasi (Sig. 2-tailed) Equal variances assumed sebesar $=$ Sig. 0,21 < 0,05. Maka dapat diketahui adanya perbedaan rata-rata hasil belajar siswa antara menggunakan metode Edutainment.

\section{SIMPULAN}

Berdasarkan hasil penelitian yang terlah dilakukan, maka dapat disimpulkan bahwa keterampilan berbicara siswa sebelum diterapkannya metode Edutainment melalui permainan simak-ulang-ucap memiliki rata-rata sebesar 51,40 pada kelas kontrol, dan 41,25 pada kelas eksperimen.

Keterampilan berbicara siswa setelah diterapkannya metode Edutainment melalui permainan simak-ulang-ucap pada kelas eksperimen, menghasilkan rata-rata sebesar 63,43.

Setelah menerapkan metode Edutainment melalui permainan simak-ulang-ucap selama 3 kali pertemuan, dapat diilhat adanya perbedaan rata-rata pada kelas eksperimen yaitu sebesar 43,94\% atau sekitar 0,43 yang termasuk dalam kategori Average. Selain itu, metode dan permainan ini mendapatkan respon yang positif dari siswa.

\section{DAFTAR PUSTAKA}

Agustriana, N. (2013). Pengaruh Metode Edutainment dan Konsep Diri Terhadap Keterampilan Sosial Anak. Jurnal Pendidikan Usia Dini, 7(2), 1-20.

Armani. (2014). Metode Edutainment untuk Meningkatkan Kemampuan Berbicara Pada Siswa Sekolah Dasar. Pontianak: Universitas Tanjungpura.

Effendy, A. F. (2009). Metodologi Pembelajaran Bahasa Arab. Malang: Misykat. 
ALSUNIYAT: Jurnal Penelitian Bahasa, Sastra, dan Budaya Arab

Harahap, Partomuan. (2017). Perbandingan Pengajaran Keterampilan Berbicara Bahasa Arab dan Bahasa Inggris di Sekolah Tinggi Agama Islam Negeri Curup. ARABIYATUNA : Jurnal Bahasa Arab. 1(2). 153-178.

Iskandarwassid \& Sunendar. (2011). Strategi Pembelajaran Bahasa. Bandung: Remaja Rosdakarya.

Maghfuro dan Adrianinsih. (2014). Metode Edutainment Bermedia Video Terhadap Hasil Belajar IPA Anak Autis di Kelas Khusus SDNP Surabaya. Jurnal Pendidikan Khusus. 6 (6), $1-6$.

Mariyaningsih \& Hidayati. (2018). Bukan Kelas Biasa: Teori dan Praktik Berbagai Model dan

Metode Pembelajaran Menerapkan Inovasi Pembelajaran di Kelas-Kelas Inovatif. Surakarta: Kekata Publisher.

Mukrima, Syifa S. (2014). 53 Metode Pembelajaran. Bandung: Universitas Pendidikan Indonesia.

Nisa', I. (2015). Peningkatan Kemampuan Berbicara Bahasa Arab Melalui Metode Eklektik Permainan "Tebak Tepat Pasanganmu" Pada Peserta Didik Kelas XI IPA-2 MAN Kendal. Skripsi. Fakultas Bahasa dan Seni. Universitas Negeri Semarang.

Nuryana \& Purwanto. (2010). Efektivitas Brain Gyn dalam Meningkatkan Konsentrasi Belajar Pada Anak. Jurnal Ilmiah Berskala Psikologi. 12(1), 89-98.

Ratnasari, N. K. W., Arini, N. W., dan Murda, I. N. (2016). Penerapan Metode Simak-Ulang-Ucap Berbantuan Media Audi untuk Meningkatkan Keterampilan Berbicara Pada Mata Pelajaran Bahasa Indonesia untuk Siswa Kelas II. E-Journal Pendidikan Guru Sekolah Dasar. 4(1), 1-12.

Shalihah, H H. (2018). Penerapan Metode Make a Match Berbasis Pancingan Kata untuk Meningkatkan Kemampuan Menulis Bahasa Arab. AISUNIYAT: Jurnal Penelitian Bahasa, Sastra, dan Budaya Arab, 1 (2), 137-145.

Sulastri, Wiji Ika. (2016). Pengembangan Media Pembelajaran Interaktif dengan Macromedia

Flash 8 Pada mata Pelajaran Korespondensi. Jurnal Administrasi Perkantoran. 4(1), 1-15. Sundayana, Rostina. (2014). Statistika Penelitian Pendidikan. Bandung: Alfabeta.

Suryani, E. (2012). Peningkatan Kemampuan Menyimak Cerita Anak Dengan Metode Simak Ulang Ucap Pada Mata Pelajaran Bahasa Indonesia Siswa Kelas V Madrasah Ibtidaiyah Swasta Rumbio Kecamatan Kampar Kabupaten Kampar. Skripsi. Fakultas Tarbiyah dan Keguruan. UIN SUltan Syarif Kasim Riau, Pekanbaru. 
ALSUNIYAT: Jurnal Penelitian Bahasa, Sastra, dan Budaya Arab

Tarigan, H. G. (2008). Menyimak Sebagai Keterampilan Berbahasa. Bandung: Angkasa. 